\title{
PENGARUH PENDIDIKAN, PENDAPATAN, USIA TERHADAP LITERASI KEUANGAN PADA BANK SYARIAH (STUDI MASYARAKAT KOTA CIKARANG)
}

\author{
Nurul Setianingrum \\ Program studi Manajemen \\ Universitas SarjanawiyataTamansiswa Yogyakarta \\ e-mail : nurulsetianingrum0@gmail.com
}

\begin{abstract}
This study discusses education, income, age and the influence of financial literacy in Islamic banks (community study in the city of Cikarang) the independent variable consists of education, income and age. While the dependent variable is financial literacy. This study uses questionnaires distributes as many as 100 questionnaires. The sample used inthis study is Cikarang city community that is sold in the Jababeka area using an Islamic bank. Data analysis technique used is assumption test, hypotesisi test, $R$ test and multiple linear regerssion. The evaluation result show education, income considering the financial literacy, age not considering the financial aspects of Islamic banks. These result indicate that the public must increase understanding of Islamic banks, especially in the differences between islamic banks and konventional banks. It is hoped that the islamic banks will increase public awareness of islamic banks in the city of Cikarang Jababeka.
\end{abstract}

\begin{abstract}
ABSTRAK
Penelitian ini bertujuan untuk meneliti apakah pendidikan, pendapatan, usia bepengaruh terhadap literasi keuangan pada bank syariah (studi masyarakat kota Cikarang). Variabel independen terdiri dari pendidikan, pendapatan dan usia. Sedangkan variabel dependen adalah literasi keuangan. Penelitian ini menggunakan kuisioner yang disebarkan sebanyak 100 kuisioner. Sampel yang dipakai dalam penelitian ini merupakan masyarakat kota cikarang terutama kawasan Jababeka yang menggunakan bank syariah. Teknik analisis data yang digunakan yaitu uji asumsi klasik, uji hipotesis dan regresi linier berganda. Hasil pengujian menunjukkan bahwa pendidikan, pendapatan berpengaruh terhadap literasi keuangan sedangkan usia tidak berpengaruh terhadap literasi keuangan pada bank syariah. Hasil tersebut menunjukkan bahwa masyarakat harus lebih meningkatkan pemahaman akan bank syariah, terutama dalam perbedaan antara bank syariah dengan bank konvensional. Diharapkan pihak bank syariah lebih meningkatkan sosialisasi kepada masyarakat akan bank syariah terutama di kota Cikarang kawasan Jababeka.
\end{abstract}

Kata Kunci : Pendidikan, pendapatan, usia, Literasi keuangan, financial literacy

\section{PENDAHULUAN}

Perkembangan sektor keuangan menjadi salah satu pemicu penentu meningkatnya perekonomian di suatu negara (Hidayati \& Anwar, 2018) Perkembangan bank syariah pertama kali berada di wilayah Timur Tngah yaitu dengan didirikannya Mit Ghamr Local Saving bank pada tahun 1963 yang kemudian diikuti oleh Nasir Social Bank pada tahun 1967. (Ismanto, 2018)

Perkembangan bank syariah di Indonesia memang sedikit terlambat dibandingkan dengan negara lain. Pada tahun 1992 berdirilah bank Muamalat yang menjadi bank syariah 


\section{Buletin Ekonomi}

pertama di Indonesia (Rama, 2015). Hingga pada tahun 1998 di Indonesia hanya terdapat 78 Badan Perkreditan Rakyat Syariah (BPR). (Rama, 2015). Keterlambatan perkembangan bank syariah dikarenakan adanya beberapa faktor, seperti belum memadainya sumber daya manusia yang berpengalaman dan kompeten, kurangnya pengembangan jiwa kepemimpinan, terbatasnya modal yang dimiliki serta masih rendahnya pengetahuan masyarakat tentang lembaga keuangan syariah. (Rusydiana, 2016). Selain hal tersebut, masyarakat juga masih kesulitan dalam memenuhi persyaratan untuk memperoleh produk atau jasa bank syariah karena tingkat pendidikan yang masih rendah serta penghasilan yang masih terbatas sehingga belum memadai untuk mengakses produk atau jasa bank syariah (Sardiana, 2018).

Berdasarkan survey yang dilakukan oleh Byrne\&Alistair (2007) dalam (Ramadhan, 2017) rendahnya tingkat literasi keuangan dapat menyebabkan rencana pembuatan keuangan yang salah dan pencapaian kesejahteraan di usia yang tidak produktif lagi. Seseorang dengan tingkat pendidikan yang tinggi maka tingkat literasinya juga tinggi. tingkat literasi keuangan memiliki korelasi dengan pendapatan (Hidayati \& Anwar, 2018).

Tingkat pendidikan memiliki pengaruh terhadap tingkat literasi, dimana seseorang yang memiliki tingkat pendidikan tinggi maka akan memiliki kesadaran yang tinggi terhadap tingkat literasi kauangan (Scheresberg,2013) dalam (Margaretha \& Sari, 2015)

Selain pendidikan, tingkat pendapatan juga berpengaruh terhadap literasi keuangan, dimana orang yang lebih tua dengan pendapatan yang lebih tinggi maka literasi keuangannya pun akan tinggi, hal ini di karenakan mereka lebih sering menggunakan layanan keuangan (Keown,2011) dalam Selain itu, semakin besar pendapatan seseorang maka akan semakin mudah dalam memenuhi kebutuhannya. (Panghayo \& Musdholifah, 2018)

Namun hal berbeda disampaikan oleh Rustiaria dan Silvi (2017) dalam (Hidayati \& Anwar, 2018) yang menyatakan bahwa tingkat pendidikan berpengaruh negatif terhadap literasi keuangan. Selain itu, untuk pendapatan juga tidak berpengaruh signifikan terhadap literasi keuangan (Kholifah dan Iramani,2013) dalam (Hidayati \& Anwar, 2018).

Perbedaan tingkat literasi juga dipengaruhi oleh tingkat usia. Dimana semakin dewasa usia seseorang maka akan semakin tinggi pula pemahaman tentang literasi keuangan. Seseorang dengan usia 25-34 tahun memiliki tingkat literasi yang lebih tinggi dibandingkan dengan seseorang dengan usia 18-24 tahun (The Social Research Centre, 2011) dalam (Margaretha \& Sari, 2015) Selain itu, semakin tinggi usia seseorang maka akan semakin baik pengetahuan dan pemahaman seseorang mengenai keuangan dan semakin baik dalam pengambilan investasi (Medhury,2013) dalam (Margaretha \& Sari, 2015)

Hal lain mengatakan bahwa tingkat literasi keuangan dipengaruhi oleh jenis kelamin, pendidikan, pendapatan sifat pekerjaan, sedangkan wilayah geografis dan usia tidak mempengaruhi literasi keuangan (Bushan dan Medhury, 2013) dalam (Margaretha \& Sari, 2015). Penelitian lain juga mengataan bahwa usia tidak berpengaruh positif terhadp literasi keuangan Usia tidak berpengaruh terhadap literasi keuangan, karena pada masa usia muda, kurang dari 20 tahun mereka biasanya memiliki rasa ingin tahu yang tinggi.(Rasmini, 2018) Terlebih lagi karena adanya perkembangan ilmu tenologi yang semakin canggih digunakan oleh usia muda sebagai ajang untuk menggali informasi.

Karena adanya perbedaan pendapat dari penelitian terdahulu yang disampaikan pada latar belakang, maka peneliti merasa tertarik untuk melakukan penelitian tentang : 1. Apakah pendidikan berpengaruh terhadap literasi keuangan pada bank syariah di Kota Cikarang ? 2. Apakah pendapatan berpengaruh terhadap literasi keuangan pada bank syariah di Kota Cikarang ? 3. Apakah usia berpengaruh terhadap literasi keuangan pada bank syariah di Kota Cikarang ? 4. Apakah pendidikan, pendapatan, usia berpengaruh terhadap literasi keuangan pada bank syariah di Kota Cikarang? 


\section{Buletin Ekonomi}

\section{Pengertian Pendidikan}

Pendidikan merupakan suatu proses mengubah sikap dan tata laku seseorang ataupun kelompok dalam usaha untuk mendewasakan manusia melalui berbagai pengajaran dan juga peralatan (KBBI). Pendidikan juga diartikan sebagai tingkat penguasaan ilmu yang dimilliki seseorang untuk menguur kemampuan yang dimilinya dengan baik.(Erwin, Cholid, \& Kristin, 2018). Pendidikan merupakan sarana bagi mansia untukan memperoleh wawasan dan pengetahuan serta mengembangkan rasa tanggung jawab baik untuk diri sendirimaupun orang lain. Pendidikan mengajarkan setiap orang harus dapat mengelola keuangan dengan baik. (panghayo,mushdolifah:2018).

Pengertian Pendapatan

Menurut biro statistik, pendapatan merupakan imbalan yang diterima oleh seseoarang baik dalam bentuk uang ataupun dalam bentuk barang yang dibayarkan oleh perusahaan/ majikan atas suatu pekerjaan yang dilakukan seseoarang. Imbalan dalam bentuk barang dinilai dengan harga setempat. (Hartanti, 2018)

Pengertian Usia

Usia adalah ukuran waktu dari keadaan sesuatu, baik yang hidup maupun yang mati. Usia merupakan tingkatan hidup yang mempengaruhi kondisi fisik seseorang (Tsalitsa \& Rachmansyah, 2016).

Pengertian Literasi Keuangan

Literasi keuangan atau Financial Literacy adalah tingkat pemahaman, keterampilan, keyakinan masyarakat terkait lembaga keuangan serta produk dan jasanya yang dituangkan dalam parameter ukuran indeks (Otoritas Jasa Keuangan, 2016)dalam (Hartanti, 2018).

Pengembangan Hipotesis

1. Pengaruh pendidikan terhadap literasi keuangan masyarakat pada bank syariah.

Pendidikan merupakan sarana bagi mansia untukan memperoleh wawasan dan pengetahuan serta mengembangkan rasa tanggung jawab baik untuk diri sendirimaupun orang lain. Pendidikan mengajarkan setiap orang harus dapat mengelola keuangan dengan baik. (Panghayo \& Musdholifah, 2018)

Terdapat pengaruh yang positif antara tingkat pendidikan terhadap literasi keuangan, semakin tinggi pendidikan maka semakin tinggi tingkat literasi keuangannya (Panghayo \& Musdholifah, 2018). Hal serupa juga sesuai dengan yang dikatakan (Tsalitsa \& Rachmansyah, 2016).

H1 : Tingkat pendidikan berpengaruh terhadap literasi keuangan masyarakat pada bank syariah.

2. Pengaruh pendapatan terhadap literasi keuangan masyarakat pada bank syariah.

Pendapatan merupakan sesuatu yang menjadi hal penting karena dengan pendapatan manusia dapat memenuhi kebutuhan hidupnya.

Tingkat pendapatan juga berpengaruh terhadap literasi keuangan, dimana orang yang lebih tua dengan pendapatan yang lebih tinggi maka literasi keuangannya pun akan tinggi, hal ini di karenakan mereka lebih sering menggunakan layanan keuangan. (Yusnita \& Abdi, 2018). Individu yang memiliki tingkat pendapatan yang tinggi, maka akan lebih paham tentang lembaga keuangan yang ada.

$\mathrm{H} 2$ : Tingkat pendapatan berpengaruh terhadap literasi keuangan bank syariah.

3. Pengaruh usia terhadap literasi keuangan masyarakat pada bank syariah.

Usia merupakan suatu pengukuran tentang lamanya suatu keadaan, baik benda yang hidup ataupun benda mati. Seseorang dengan usia 25-34 tahun memiliki tingkat literasi yang lebih tinggi dibandingkan dengan seseorang dengan usia 18-24 tahun (The Social Research Centre, 2011) dalam (Margaretha \& Sari, 2015). Selain itu, semakin tinggi usia seseorang maka akan semakin baik pengetahuan dan pemahaman seseorang mengenai keuangan dan 


\section{Buletin Ekonomi}

semakin baik dalam pengambilan investasi (Medhury,2013) dalam (Margaretha \& Sari, 2015).

H3 : Usia berpengaruh terhadap literasi keuangan bank syariah.

4.Pengaruh pendidikan, pendapatan, usia terhadap literasi keuangan pada bank syariah.

Faktor demografi dapat menjelaskan kondisi dan perubahan masyarakat. Dimana dengan adanya perbedaan kondisi sosial ekonomi dalam masyarakat akan menimbulkan perbedaan persepsi. Seseorang yang memiliki pandangan tentang keuangan yang lebih tinggi akan paham entang literasi keuangan(Rasmini, 2018). Pendidikan, pendapatan, jenis kelamin dan usia berpengaruh terhadap literasi keuangan (Erwin et al., 2018)

H4 : Pendidikan, pendapatan dan usia berpengaruh terhadap liteasi keuangan pada bank syariah.

\section{METODE}

Jenis penelitian ini adalah penelitian kuantitatif dan statistik yang dgunakan dalam penelitian ini adalah statistik deskriptif. Tujuan dari penelitian ini adlah untuk mengetahui ada atau tidaknya pengaruh variabel independen seperti pndidikan, pendapatan, usia terhadap variabel dependen lietrasi keuangan pada bank syariah di Kota Cikarang.

Populasi yang digunakan dalam penelitian ini adalah masyarakat kota Cikarang dengan kriteria berumur minimal 17 dan sudah bekerja. Jumlah sampel yang digunakan sebanyak 100 responden. Tenik pengambilan sampel menggunakan teknik simple random yaitu memberikan kuisioner kepada responden secara langsung di lapangan tanpa membedabedakan.

Data yang digunakan adalah data primer, teknik pengambilan data dengan cara menyebar kuisioner. Kuisioner yang digunakan dalam penelitian ini menggunakan kuisioner pilihan ganda dimana setiap sola diberikan 5 pilihan jawaban. Skor untuk menghitung nilai setiap jawaban menggunakan skala likert. Penelitian ini menggunakan teknik analisis data dengan uji asumsi klasik, uji regresi linier berganda uji hipotesis, dan uji R.

\section{ANALISIS DAN PEMBAHASAN}

Penelitian ini dilakukan di Cikarang dengan responden penelitian adalah masyarakat kota Cikarang yang menjadi nasabah bank syariah. Berdasarkan hasil penelitian, sebagai berikut, Uji asumsi Klasik : 


\section{Buletin Ekonomi}

Tabel Uji Normalitas

One-Sample Kolmogorov-Smirnov Test

\begin{tabular}{ccr}
\hline & & literasi \\
$\mathrm{N}$ & & 100 \\
\hline Normal & Mean & 38,84 \\
Parameters $^{\mathrm{a}, \mathrm{b}}$ & Std. & 5,447 \\
& Deviation & \\
Most & Absolute &, 129 \\
Extreme & Positive &, 073 \\
Differences & Negative &,- 129 \\
& Kolmogorov-Smirnov Z & 1,287 \\
Asymp. Sig. (2-tailed) &, 073 \\
\hline
\end{tabular}

a. Test distribution is Normal.

b. Calculated from data.

Berdasarkan hasil dari uji normalitas, nilai Asymp.sig. (2-tailed) sebesar 0,73 yang berarti lebih besar dari 0,05 sehingga penenitin dikatakan normal.

1. Uji Heteroskedastisitas

Berdasarkan hasil uji yang dilakukan, diketahui nilai signifikansi untuk pendidikan sebesar 1,00, untuk pendapatan 1,00 dan untuk usia 1,00 yang lebih besar dari 0,05 sehingga dikatakan tidak terjadi gejala heteroskedastisitas.

2. Uji multikolinearitas

Berdasarkan hasil uji yang dilakukan, maka nilai tolernce untuk pendidikan sebesar 0,801 , untuk pendapatan 0,816 dan usia 0,951 yang beararti diatas 0,1 dan nilai VIF untuk pendidikan sebesar 1,248 untuk pendapatan VIF 1,225 dan untuk usia VIF sebesr 1,052. Yang berarti $<10$ sehingga tidak tejadi multikol.

Uji Regresi Linier Berganda .

Berdasarkan hasil uji regresi linier maka dapat disimpulkan sebagai berikut

$\mathrm{Y}=\mathrm{a}+\mathrm{bPDK}+\mathrm{bPDT}+\mathrm{bU}+\mathrm{e}$

$\mathrm{Y}=15,360+3,778 \mathrm{PDK}+2,700 \mathrm{PDT}-0,168 \mathrm{U}+\mathrm{e}$

Uji Hipotesis

1. Uji t (parsial)

Berdasaran hasil dari uji t maka dapat diketahui nilai $\mathrm{t}$ hitung untuk pendidikan sebesar 7,541 > 1,984989 (t hitung) dengan nilai signifikansi $0,00<0.05$ sehingga $\mathrm{H} 1$ diterima.

$\mathrm{H} 1$ = pendidikan berpengaruh terhadap literasi keuangan

Untuk pendapatan, nilai t hitung sebesar 6,281 >1,98498 (t tabel) dengan nilai signifikansi sebesar 0,00>0,05 yang berarti bahwa $\mathrm{H} 2$ diterima

$\mathrm{H} 2$ = pendapatan berpengaruh terhadap literasi keuangan.

Untuk usia, nilai t hitung sebesar $-1,390<1,98498$ ( $\mathrm{t}$ tabel) dengan nilai signifikansi sebesar 0,168>0,05 sehingga $\mathrm{H} 3$ ditolak

$\mathrm{H} 3$ = usia tidak berpengruh terhadap literasi keuangan. 


\section{Buletin Ekonomi}

\section{Uji F (simultan)}

Berdasarkan hasil dari pengujian, maka didapatkan nilai $\mathrm{F}$ sebesar 56,921 > dari $\mathrm{F}$ tabel yaitu 2,70 sehingga dapat diambil kesimpulan H0 diterima. Pendidikan, pendapatan, usia berpengaruh secara simultan terhadap literasi keuangan

Uji R

Hasil dari uji $\mathrm{R}$ mendapatkan nilai $\mathrm{R}$ Square sebesar 0,640 yang berarti bahwa variabel pendidikan, pendapatan, usia berpengaruh sebesar 0,640 terhadap lietasi keuangan.

\section{Pembahasan}

1. Tingkat Pendidikan Berpengaruh Terhadap Literasi Keuangan Pada Bank Syariah.

Pada uji hipotesis pendidikan (X1) memiliki nilai signifikan sebesar $0.000<$ dari 0.05 dan $t$ hitung sebesar 7,541 > dari t tabel 1.98498. Sehingga dapat dikatakan bahwa tingkat pendidikan berpengaruh positif terhadap literasi keuangan pada bank syariah.

Hal ini sesuai dengan pendapat dari Tsalitsa dan Rahmansyah (2016) yang mengatakan bahwa pendidikan berpengaruh dalam pengambilan keputusan seseorang, semakin tinggi tingkat pendidikan yang dimiliki akan semakin banyak pengetahuan yang dimiliki sehingga akan lebih teliti dalam pengambilan keputusan dan mempertimbangkan segala keputusan

2.Tingkat Pendapatan Berpengaruh Terhadap Literasi Keuangan Pada Bank Syariah

Pada uji hipotesis variabel pendapatan (X2) memiliki nilai signifikan sebesar $0.000<$ dari 0.05 dan memiliki nilai $t$ hitung sebesar 6,281 > dari t tabel 1.98498. Sehingga dapat disimpulkan bahwa pendapatan berpengaruh positif terhadap literasi keuangan.

Hasil ini juga sesuai dengan pendapat dari Yusnita dan Abadi (2018) yang mengatakan tingkat pendapatan juga berpengaruh terhadap literasi keuangan, dimana orang yang lebih tua dengan pendapatan yang lebih tinggi maka literasi keuangannya pun akan tinggi, hal ini di karenakan mereka lebih sering menggunakan layanan keuangan.

3.Tingkat Usia Berpengaruh Terhadap Literasi Keuangan Pada Bank Syariah

Pada uji hipotesis vaiabel usia (X3) memiliki nilai signifikansi sebesar $0.168>$ dari 0.05 dan nilai $t$ hitung sebesar $-1,390<$ dari t tabel 1,98498. sehingga dapat disimpulkan bahwa usia tidak berpengaruh terhadap literasi keuangan.

Hasil ini menolak pengujian Margaretha (2015) yang mengatakan Seseorang dengan usia 25-34 tahun memiliki tingkat literasi yang lebih tinggi dibandingkan dengan seseorang dengan usia 18-24 tahun. Selain itu, semakin tinggi usia seseorang maka akan semakin baik pengetahuan dan pemahaman seseorang mengenai keuangan dan semakin baik dalam pengambilan investasi.

4.Tingkat Literasi Keuangan Pada Bank Syariah Di Kota Cikarang

Berdasarkan tabel variabel terikat (Y) literasi keuangan memiliki nilai Alpha sebesar $0.774>$ dari 0.6 maka variabel literasi keuangan dikatakn reliabel. Secara keseluruhan memiliki nilai Asymp Sig $0.073>$ dari 0.05 maka terdistribusi normal.

5.Berdasarkan hasil uji f dapat di ketahui bahwa nilai f hitung sebesar 56,921 > dari 2,70 f hitung, sehingga disimpulkan bahwa pendidikan, pendapatan, usia berpengaruh secara simultan terhadap lterasi keuangan.

\section{KESIMPULAN DAN SARAN}

Berdasarkan hasil analisis data diatas dan pembahasan tentang pengaruh pendidikan, pendapatan, usia terhadap literasi keuangan masyarakat pada bank syariah, maka dapat diambil kesimpulan sebagai berikut :

1. Variabel Pendidikan berpengaruh secara signifikan terhadap literasi keuangan masyarakat pada bank syariah dimana masyarakat dengan pendidikan yang lebih tinggi 


\section{Buletin Ekonomi}

memiliki literasi keuangan yang semakin baik. Sehingga dapat disimpulkan bahwa pendidikan berpengaruh signifikan positif terhadap literasi keuangan.

2. Variabel Pendapatan berpengaruh secara signifikan terhadap literasi keuangan masyarakat pada bank syariah dimana masyarakat yang memiliki pendapatan lebih tinggi akan memiliki literasi keuangan yang baik, dikarenakan mereka paham tentang pengelolaan keuangan yang baik.

3. Variabel Usia tidak berpengaruh secara signifikan terhadap literasi keuangan masyarakat pada bank syariah, hal ini sesuai dengan uji hipotesis yang sudah dilakukan. Sehingga usia bukan faktor yang dapat mempengaruhi literasi.

Dalam uji f dinyatakan bahwa pendidikan, pendapatan dan usia berpengaruh secara simultan terhadap literasi keuangan masyarakat pada bank syariah.

\section{DAFTAR PUSTAKA}

Budisantoso,Totok\&Nuritomo.2017.Bank dan Lembaga Keuangan lain Edisi 3.Jakarta:Salemba Empat.

Erwin, Cholid, I., \& Kristin, U. (2018). Analisis pengaruh usia, jenis kelamin, pendidikan dan pendapatan terhadap tingkat literasi keuangan (studi kasus konsumen cv.sejahtera abadi). $1-5$.

Hartanti, ratna eka. (2018). Pengaruh usia, jenis kelamin, tempat tinggal, pendidikan dan pendapatan terhadap tingkat literasi keuangn asuransi syariah studi kasus pada pedagang pasar gede hardjonagoro solo.

Hidayati, S. N., \& Anwar, M. K. (2018). Pengaruh faktor demografi terhadap literasi keuangan syariah karyawan perbankan syariah di Surabaya . Jurnal Eonomi Islam, $1(1), 1-12$.

Ismanto, K. (n.d.). Literasi masyarakat dan dampaknya terhadap minat menjadi nasabah bank syariah

Margaretha, F., \& Sari, S. M. A. Y. (2015). Faktor penentu tingkat literasi keuangan para pengguna kartu kredit di Indonesia. Jurnal Akuntansi\&investasi, 16(2), 132-144. https://doi.org/10.18196/JAI-2015.0038

OJK. (2016). Survei nasional literasi dan inklusi keuangan 2016.

Panghayo, N. A., \& Musdholifah, M. (2018). Pengaruh literasi keuangan terhadap pemilihan layanan keuangan syariah. Journal of Islamic Economis, 2(2), 152-167.

Putri, ni made dwiyana rasuma, \& Rahyuda, H. (2017). Pengaruh tingkat financyal literacy dan faktor sosiodemografi terhadap perilaku keputusan investasi individu. $E$ Jurnal Ekonomi Dan Bisnis Universitas Udayana, 6(9), 3407-3434.

Rama, A. (2015). Analisis deskriptif perkembangan perbankan syariah di asia tenggara. The Journal of Tauhidinomics, 1(2), 105-123.

Ramadhan, R. (2017). Determinan tingkat literasi keuangan masyarakat pada lembaga 


\section{Buletin Ekonomi}

keuangan syariah.

Rasmini, M. (2018). Analisis literasi keuangan dan faktor-faktor yang mempengaruhinya . Jurnal Ilmu Politik Dan Komunikasi, VIII(2).

Rusydiana, aam slamet. (2016). Analisis masalah pengembangan perbankan di Indonesia. Jurnal Bisnis Dan Manajemen, 6(2), 237-246. https://doi.org/10.15408/ess.v6i2.3573

Said, S., \& Amiruddin, andi muhammad ali. (2017). Literasi Keuangan Syariah di Perguruan Tinggi Keagamaan Islam ( Studi Kasus UIN Alauddin Makasar ). Al-Ulum, 17(1), 44-64. https://doi.org/10.9744/jmk.17.1.76

Sardiana, A. (2018). Preferensi penggunaan jasa keuangan bank syariah berdasarkan literasi keuangan syariah.

Shinta Dewi, Oktavia.2019. Pengaruh Pendidikan, Keterampilan dan Kedisiplinan Kerja Terhadap Kinerja Pengrajin Pada Sentra Industri Perak di Kota Gedhe Yogyakarta. Yogyakarta: UST

Taurisa, chaterina melina, \& Ratnawati, I. (2012). Analisis pengaruh budaya oganisasi dan kepuasan kerja terhadap komitmen organisasional dalam meningkatkan kinerja karyawan(Studi pada PT. Sido Muncul Kaligawe Semarang). Jurnal Bisnis Dan Ekonomi, 19(2), 170-187.

Tsalitsa, A., \& Rachmansyah, Y. (2016). Analisis pengaruh literasi keuangan dan faktor demografi terhadap pengambilan kredit pada PT. Columbia cabang Kudus. Media ekonomi dan manajemen. Vol. 31 No. 1 Januari 2016. 31(1), 1-13.

Yusnita, R. R., \& Abdi, M. (2018). Pengaruh faktor demografi terhadap literasi keuangan. Journal of Economic, Business and Accounting, 2(1), 163-184. 